\title{
EFFECT OF TEMPERATURE ON CLOSTRIDIUM SP. STRAIN PXL2 AND REMOVAL OF ARSENIC AND NITRATE FROM GROUNDWATER
}

\author{
LI, B. H. ${ }^{1,2}-$ PAN, X. L..$^{2,3 *}$ \\ ${ }^{1}$ Xinjiang Institute of Engineering, Urumqi 830091, China \\ ${ }^{2}$ Laboratory of Environmental Pollution and Bioremediation, Xinjiang Institute of Ecology and \\ Geography, Chinese Academy of Science, Urumqi 830011, China \\ ${ }^{3}$ College of Environment, Zhejiang University of Technology, Hangzhou 310014, China \\ *Corresponding author \\ e-mail:panxl@zjut.edu.cn; phone: +86-0571-88871577
}

(Received $5^{\text {th }}$ Nov 2018 ; accepted $4^{\text {th }}$ Feb 2019)

\begin{abstract}
Anaerobic Fe(II) Oxidation DeNitrifiers (AFODN) have recently been proposed as an option to treat groundwater contaminated by arsenic and nitrates through oxidation of microbiological nitratedependent ferrous oxidation. In previous studies, a pure strain of AFODN bacteria, Clostridium sp. Strain PXL2, was isolated from anoxic activated sludge. In this paper, the growth curve of strain PXL2 is studied under different temperature conditions, along with its $\mathrm{Fe}(\mathrm{II})$ oxidation, nitrate reduction, and arsenic removal efficiency. The results showed that at $5^{\circ} \mathrm{C}$, the growth of the strain was significantly inhibited. At $15^{\circ} \mathrm{C}$, the metabolic rate of growth, denitrification and $\mathrm{Fe}$ (II) oxidation rate were optimum and the total arsenic removal rate was high at $51.1 \%$. The strain PXL2 can remove nitrate and arsenic contamination at the same time under normal groundwater temperature conditions. These analyses provide the necessary data to support the application of AFODN in engineering projects.
\end{abstract}

Keywords: denitrification, iron oxide minerals, heavy metal, bioremediation, synchronize

\section{Introduction}

Section title Arsenic contamination in water bodies due to the release of untreated industrial wastewaters has been on the rise due to excessive mining and smelting. The prevalence of arsenic and its compound in water bodies grows more serious every day and currently threatens the lives of more than 140 million people around the world (Karim, 2000; Smedley and Kinniburgh, 2002; Singh et al., 2007; Song et al., 2017). In China alone, it is estimated that more than 3 million people are exposed to elevated levels of As (Sun, 2004). New endemic areas have been progressively identified, such as the Huhot Basins in Inner Mongolia (Guo et al., 2001) and the Datong Basin in Shanxi Province (Wang et al., 2007) since the first case of chronic As poisoning was observed in the Xinjiang autonomous region in 1980 (Wang and Huang, 1994). Populations in affected areas suffer from melanosis, keratosis in their palms and soles, gangrene, and even skin cancer.

Among the numerous reduction processes of the soluble matrix, NO3- reduction plays a key role in the nitrogen cycle and has important implications for agriculture, environmental health, and public health (Shen et al., 2010; Xing et al., 2010). Natural nitrate attenuation is driven by microbial enzyme reduction, although, the abiotic reduction of nitrate also occurs under some extreme conditions (Hansen et al., 1996; Ottley et al., 1997; Zhang et al., 2014). Oxidation of microbiological nitrate-dependent $\mathrm{Fe}$ (II) to $\mathrm{Fe}(\mathrm{III})$ has been recently described with ferrous iron as the only electron donor 
and with nitrate as the electron acceptor (Straub et al., 1996; Hafenbradl et al., 1996; Straub et al., 2004; Weber et al., 2006; Chakraborty et al., 2011; Li et al., 2015). These microorganisms are called the Anaerobic Fe(II) Oxidation DeNitrifiers (AFODN) (Wu et al., 2010). Enrichments of AFODN were successfully established with a variety of marine, brackish, or freshwater sediment samples (Kappler, 2005). The metabolism of AFODN is affected by many external factors (Chen et al., 2018). The major environmental factors include temperature, salinity, carbon source, $\mathrm{pH}$, dissolved oxygen, and iron source. The oxidation of ferrous oxide directly affects the removal efficiency of heavy metals. To achieve the highest removal efficiency of nitrate and heavy metals and the best governance effect, it is necessary to provide optimum conditions for the ferrous oxidation and nitrate reduction by AFODN, which will help activate the microorganisms and lay the foundation for its application.

The response of different microorganisms to heavy metals is dependent on their physiologies $(\mathrm{Li}, 2017)$. Various treatment technologies to mitigate the severe problem of arsenic tainted groundwater have been extensively studied during last few decades (Hu et al., 2015; Niazi et al., 2018; Cui et al., 2018). Previous studies showed that low concentrations of arsenic promoted the growth of heterotrophic microorganisms. However, the growth of heterotrophic microorganisms was inhibited with the increase of As(III) concentration. While under the same exogenous arsenic concentration, it has a stronger inhibitory effect on autotrophic microorganisms than on heterotrophic microorganisms.

In this study, a novel AFODN species, the Clostridium sp. strain PXL2, was isolated from anaerobic activated sludge (Li et al., 2016), and its growth curve was studied under different temperature conditions. $\mathrm{Fe}$ (II) oxidation, nitrate reduction, and arsenic removal efficiency by strain PXL2 were observed under different temperature conditions. The resistance of strain PXL2 to arsenic, as well as its ability to oxidize microbiological nitrate-dependent $\mathrm{Fe}(\mathrm{II})$ to $\mathrm{Fe}(\mathrm{III})$ in an arsenic contaminated environment made it ideal for application in practical engineering. These analyses can provide the data necessary to support the application of AFODN in engineering projects.

\section{Experimental materials and methods}

An anaerobic nitrate-reducing Fe(II) oxidizing bacteria $C$. freundii PXL2 could synchronously remove $\mathrm{As}$ (III) and nitrate from water, associated with $\mathrm{Fe}(\mathrm{II})$ oxidation. Batch experiments were conducted to study the effect of temperature on ferrous oxidation and denitrification of PXL2 strains. SEM-EDS analyzed the morphologies under different temperature conditions. The removal of arsenic under different temperature conditions was studied at the same time. The selection medium (Li et al., 2014) was used as the culture medium with three repetitions for each sample.

Three tubes of mediums inoculated with AFODN culture were set to determine the efficiency of $\mathrm{Fe}(\mathrm{II})$ oxidation and nitrate reduction. The whole experiment was carried out in the G250 anaerobic, insuring microbial metabolism in the absence of oxygen. The amount of inoculation was $4 \%$ ( $\mathrm{vol} / \mathrm{vol})$. All the tubes were sampled every 24 hours to determine the nitrate, nitrite, and Fe(II) concentrations. The effect of temperature on the denitrification of AFODN was performed. The initial concentrations of $\mathrm{FeCl}_{2} \cdot 4 \mathrm{H}_{2} \mathrm{O}$ and $\mathrm{KNO}_{3}$ were $1 \mathrm{mM}$ and $20 \mathrm{mM}$, respectively. 
Arsenic pollution was simulated by $\mathrm{NaAsO}_{2}$ to study the removal of arsenic by strain PXL2 at different temperatures. the initial concentration of As (III) was 60-70 $\mu \mathrm{M}$ (about $5 \mathrm{mg} \mathrm{L}^{-1}$ ). To improve arsenic removal rate, the experimental analysis was extended to seven days. In addition to the analysis of total arsenic concentrations, the concentrations of As (III) and As (V) were also analyzed separately.

Concentrations of nitrate, nitrite, and $\mathrm{Fe}(\mathrm{II})$ were measured by a spectrophotometer (DU 800 UV/Vis Spectrophotometer, Beckman coulter, United States). N-( $\alpha$-naphthyl)ethylenediamine spectrophotometry was used to determine the concentrations of nitrite at $540 \mathrm{~nm}$ (Geng et al., 1996). Nitrate concentration was measured by UV spectrophotometry at $220 \mathrm{~nm}$ and $275 \mathrm{~nm}$ (Veena and Narayana, 2009). Phenanthroline spectrophotometry was used to determine Fe(II) concentration at $510 \mathrm{~nm}$ (Gendel and Lahav, 2008). For the modified phenanthroline assay, the samples were mixed with $40 \mathrm{mM}$ sulfamic acid ( $\mathrm{pH}$ approximately 1.8) instead of $25 \mathrm{vol} \% \mathrm{HCl}$ because the sulfamic acid reacted rapidly with nitrite and prevented $\mathrm{Fe}(\mathrm{II})$ oxidation by the nitrite at an acidic $\mathrm{pH}$ (Klueglein and Kappler, 2013). All the samples were measured within $2 \mathrm{~h}$ after sampling. Total As concentration was measured by an AFS-8X atomic fluorescent spectrophotometer (Jitian Instruments Co., Ltd., Beijing, China). Ten $\mathrm{ml}$ of 5\% thiourea and $5 \%$ vitamin $\mathrm{C}$ mixture and $2.5 \mathrm{ml}$ of concentrated $\mathrm{HCI}$ were added to $50 \mathrm{ml}$ of sample as $\mathrm{As}(\mathrm{V})$ reducing agent and stabilizer, respectively, and $2.0 \%$ (W/V) $\mathrm{KBH}_{4}$ and $0.5 \%(\mathrm{~W} / \mathrm{V}) \mathrm{KOH}$ were used to transform the ion state $\mathrm{As}(\mathrm{III})$ to $\mathrm{AsH}_{3}$. The flow carrier of samples was $5 \%(\mathrm{~V} / \mathrm{V}) \mathrm{HCl}$. The original As(III) concentration in the water samples was measured by the same method without the addition of the 5\% thiourea and 5\% vitamin $\mathrm{C}$ mixture. Microbial morphology was observed by a Scanning Electron Microscope (SEM) (Zeiss Super 55VP, Germany) equipped with and energy dispersive X-ray (EDX) (Bruker XFlash 5010, Germany) spectroscope. Accelerating voltages ranged from 15 to $35 \mathrm{kV}$.

All the experiments were performed in triplicates. Error bars on graphs show the standard deviation. The data were analyzed by analysis of variance and the means were compared by Tukey's test $(\mathrm{p}<0.05)$.

\section{Results and discussion}

\section{Growth curve of PXL2 strains at different temperatures}

Temperature is a major environmental factor that affects the growth of microorganisms. The temperature at which fastest microbial growth and reproduction occur is called the optimum growth temperature. The reaction rate increases with rising temperature, however, increasing temperature leads to the destruction of intracellular enzymes and nucleic acids and eventually, microbial death. Lower temperatures decrease cellular metabolic activity and lead to slow growth. A temperature that is too low triggers the formation of intracellular ice crystals that would lead to dehydration of the microorganisms and ultimately microbial death.

Based on the variation of groundwater temperature in seasonal alternations, three temperature gradients of $5^{\circ} \mathrm{C}, 15^{\circ} \mathrm{C}$ and $30^{\circ} \mathrm{C}$ were selected to study the growth and reproduction ability of PXL2 strains at different temperatures. In the selected medium access, $2 \%$ bacterial suspension were placed in $5^{\circ} \mathrm{C}, 15^{\circ} \mathrm{C}, 30^{\circ} \mathrm{C}$ anaerobic environment static cultures for $72 \mathrm{~h}$ and the absorbance of the bacterial liquid was measured at $600 \mathrm{~nm}$. The results are shown in Figure 1. As can be seen from the figure, $5^{\circ} \mathrm{C}$ obviously inhibited the growth of the strain, and the OD value of the $96 \mathrm{~h}$ bacterial 
liquid continued to decline, indicating that the strain cannot complete its metabolism at $5^{\circ} \mathrm{C}$. At $15^{\circ} \mathrm{C}$, some microbes could not adapt to the low-temperature environment and died after about $8 \mathrm{~h}$ of inoculation, after which the OD of the bacteria began to increase, indicating that the surviving microbes gradually adapted to the ambient temperature and the growth and metabolism rates were consistent with those at $30^{\circ} \mathrm{C}$. The growth, propagation and metabolism rate are the highest, the bacterial stagnation period is short, and the logarithmic phase can be quickly achieved at this temperature.

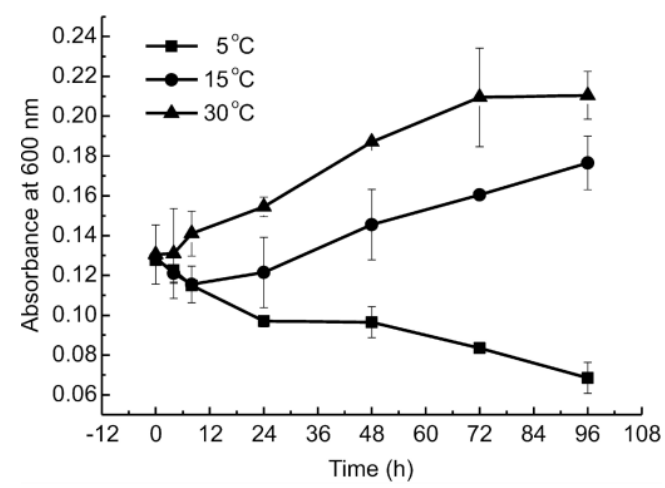

Figure 1. Growth curves of PXL2 strains at different temperatures

The optimal temperature for bacterial oxidization under ferrous anaerobic conditions is mainly related to the source of separation. Ehrenreich et al. (1994) isolated two strains of Chromatium strain L7 and Rhodobacter strain SW2 from the sediments of freshwater ditches whose optimal temperature range for growth was $18-20^{\circ} \mathrm{C}$, and found that they did not thrive at temperatures above $24^{\circ} \mathrm{C}$. Hafenbradl et al. (1996) isolated an extremely thermophilic archaeon named Ferroglobus Placidus gen. Sp. Nov. from a hydrothermal system. The optimal temperature range of this strain was $65^{\circ} \mathrm{C}$ to $95^{\circ} \mathrm{C}$ and its doubling time was about $2.8 \mathrm{~h}$. The bacteria could not grow when the environment temperature was under $63^{\circ} \mathrm{C}$ or exceeded $96^{\circ} \mathrm{C}$. AFODN strain HidR2, which was isolated from seabed sediments grew at temperatures of 5 to $40^{\circ} \mathrm{C}$ while the optimum temperature was $33^{\circ} \mathrm{C}$ (Benz et al., 1998). For two strains of photosynthetic non-ferrous anaerobic oxidative bacteria, strain $\mathrm{N} 1$ and strain $\mathrm{N} 2$, which were also separated from seafloor sediments, the optimal temperature ranges were similar to strain HidR2. The optimal growth temperature of strain $\mathrm{N} 1$ was $20-25^{\circ} \mathrm{C}$, while the optimal growth temperature of strain N2 was $25-28^{\circ} \mathrm{C}$ (Straub et al., 1999). For AFODN strains BrG1 and BrG2, which were isolated from brackish water lakes and urban ditches, their growth rate at $15^{\circ} \mathrm{C}$ was greater than that at $28^{\circ} \mathrm{C}$ (Straub et al., 1996).

The strain PXL2 was isolated from the ditch sediments. It is a normal temperature living environment. So the strain PXL2 can grow at temperatures of 5 to $30^{\circ} \mathrm{C}$. And the growth rate increases with temperature within the scope of the study.

\section{Ferrous Oxidation and Nitrate Reduction of PXL2 Strains at Different Temperatures}

The effect of temperature on the ferrous oxidation and nitrate reduction of AFODN is primarily due to the metabolic activity of the microorganism (Leahy and Colwell, 1990). The ferrous oxidation of AFODN and nitrate reduction is based on specific metabolic methods of microorganisms, and the catalytic effect of the enzyme is most efficient only within the optimum temperature range. 
Figures $2 A, B$ and $C$ show the changes of $\mathrm{Fe}$ (II), $\mathrm{NO}_{3}{ }^{-}$and $\mathrm{NO}_{2}{ }^{-}$concentrations in the medium inoculated with PXL2 strains with time at different temperatures, respectively.
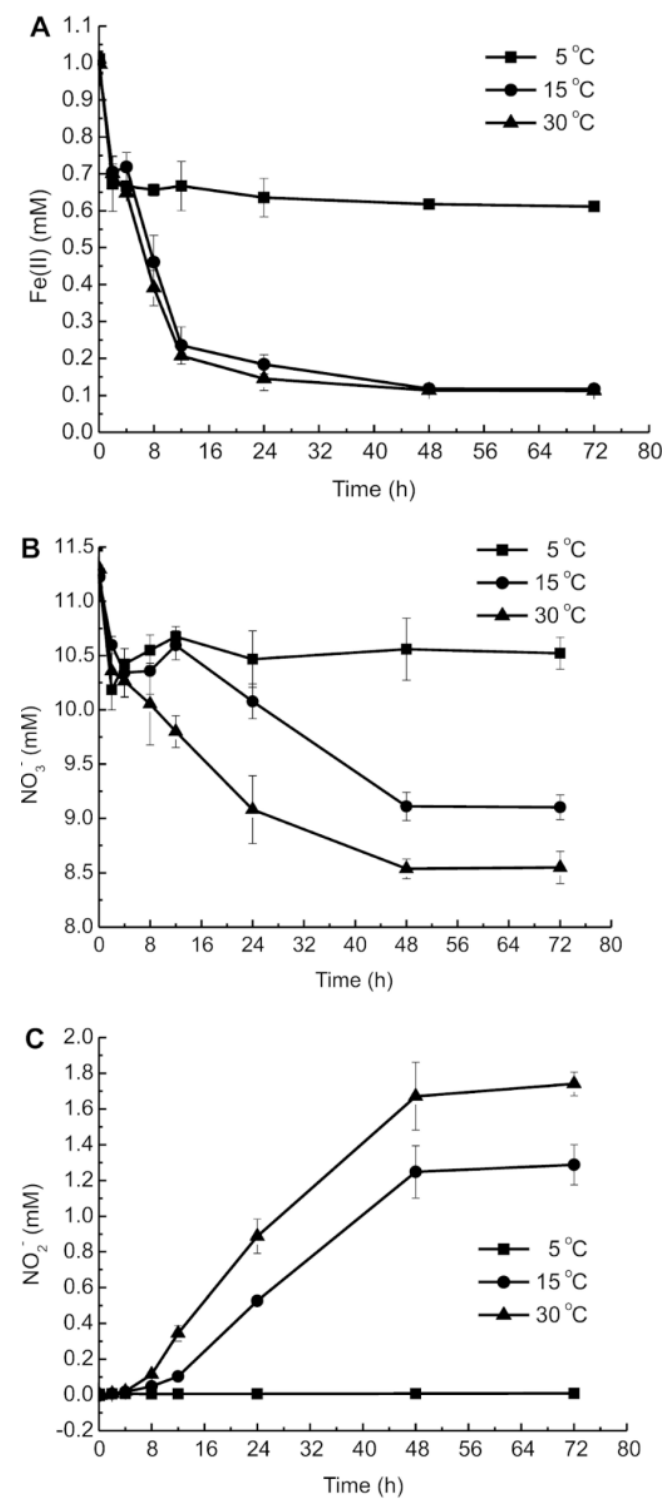

Figure 2. Time profile of $\mathrm{Fe}(\mathrm{II}), \mathrm{NO}_{3}{ }^{-}$and $\mathrm{NO}_{2}{ }^{-}$concentrations in the strain PXL2 culture at different temperatures

It can be seen from the figure that at the same oxidation rate, the temperature has little or no effect on the oxidation of ferrous ions within $4 \mathrm{~h}$ after inoculation. However, with time, the low temperature $\left(5^{\circ} \mathrm{C}\right)$ sample significantly inhibits the oxidation of $\mathrm{Fe}$ (II). At $5^{\circ} \mathrm{C}$, the ferrous oxidation rates were significantly lower than those at $15^{\circ} \mathrm{C}$ and $30^{\circ} \mathrm{C}$. The oxidation rates of ferrous iron at $15^{\circ} \mathrm{C}$ and $30^{\circ} \mathrm{C}$ were almost the same as the initial Fe (II) concentration of $1 \mathrm{mM}$. About $90 \%$ of Fe (II) was oxidized after $24 \mathrm{~h}$. Fe(II) oxidation was completed and nitrate degradation was also completed. As shown in Figure $2 B$, the nitrate degradation ability of PXL2 strains did not change significantly within $4 \mathrm{~h}$ after the completion of Fe (II) oxidation. However, with the duration of 
inoculation, nitrate degradation ability was quite different. At $5^{\circ} \mathrm{C}$, the biomass stagnated after $12 \mathrm{~h}$ of inoculation and no longer had the ability to degrade nitrate. The same degradation rate was maintained at $15^{\circ} \mathrm{C}$ and $30^{\circ} \mathrm{C}$, but strain PXL2 completed $19.5 \%$ nitrate degradation at $15^{\circ} \mathrm{C}$ after $72 \mathrm{~h}$ of inoculation, While at $30^{\circ} \mathrm{C}, 24.8 \%$ nitrate degradation was completed, which is slightly higher than that at $15^{\circ} \mathrm{C}$. The trend of accumulation of nitrite coincides with the trend of degradation of nitrate. Higher accumulation of nitrite, $1.7 \mathrm{mM}$, was observed in $30^{\circ} \mathrm{C}$ environments. The second highest concentration is the concentration of nitrite at $15^{\circ} \mathrm{C}$ reached $1.3 \mathrm{mM}$. No nitrite was accumulated in the environment at $5^{\circ} \mathrm{C}$.

The PXL2 strains showed different rates of ferrous oxidation and nitrate degradation at different temperatures, which may affect the reproduction of microorganisms. At the same time, the oxidative degradation ability of AFODN at low temperature was greatly reduced. The low temperature inhibited the growth of microorganism's intracellular enzyme activity, so that it reduced the ability of oxidation and degradation.

\section{SEM-EDS Analysis of Sediments at Low Temperatures}

SEM analysis of microbial antioxidant sediments at $5^{\circ} \mathrm{C}, 15^{\circ} \mathrm{C}$ and $30^{\circ} \mathrm{C}$ (Fig. 3) shows that the morphology of the cells changed significantly at $5^{\circ} \mathrm{C}$, the bacillus is coarsened and shortened, and obvious dents generally appear, possibly as a response to the low temperature.
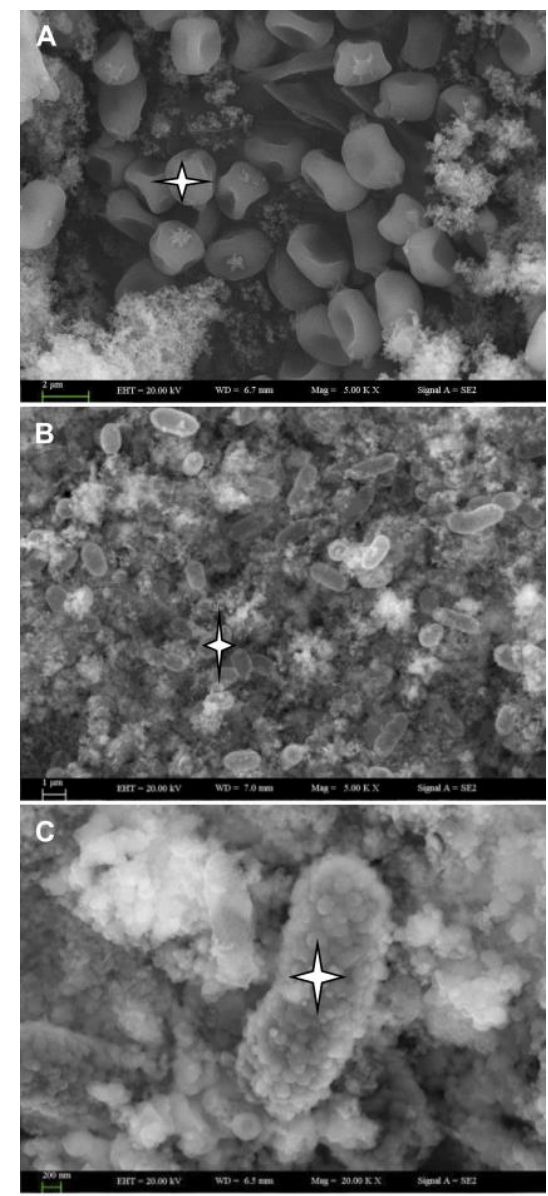

Figure 3. SEM analysis of microbial ioxidant sediments--strain PXL2 at different temperatures (The star indicated the point of EDS analysis in Figure 4. A: $5^{\circ} \mathrm{C} ; \mathrm{B}: 15^{\circ} \mathrm{C} ; \mathrm{C}: 30^{\circ} \mathrm{C}$ ) 
At $30^{\circ} \mathrm{C}$, the cells were incrusted in nanosize $\mathrm{Fe}(\mathrm{III})$ oxides with only few cells being completely free of surface precipitates (Fig. 3c). The average diameter of the Fe(III) oxides was between 100 200 $\mathrm{nm}$.

EDS analysis of ferrous oxide products at $5^{\circ} \mathrm{C}, 15^{\circ} \mathrm{C}$ and $30^{\circ} \mathrm{C}$. Figure 4 shows that the sediments formed at $5^{\circ} \mathrm{C}$ mainly consist of $\mathrm{C}$ and $\mathrm{O}$, with only a small amount of $\mathrm{Fe}$. The highest $\mathrm{C}$ content was $62.41 \%$, the content of $\mathrm{O}$ was $33.15 \%$ and the content of iron was only $0.35 \%$. The contents of $\mathrm{Fe}$ in the sediments formed at $15^{\circ} \mathrm{C}$ were higher at about $9.64 \%$, which far exceeded the content of $\mathrm{Fe}$ in the sediments formed at $5^{\circ} \mathrm{C}$. At $30^{\circ} \mathrm{C}$, EDS analysis showed that the precipitates were mainly composed of $\mathrm{C}(22.85 \%)$, $\mathrm{O}(40.68 \%)$ and $\mathrm{Fe}(22.41 \%)$. Iron content exceeds at the first two temperatures.
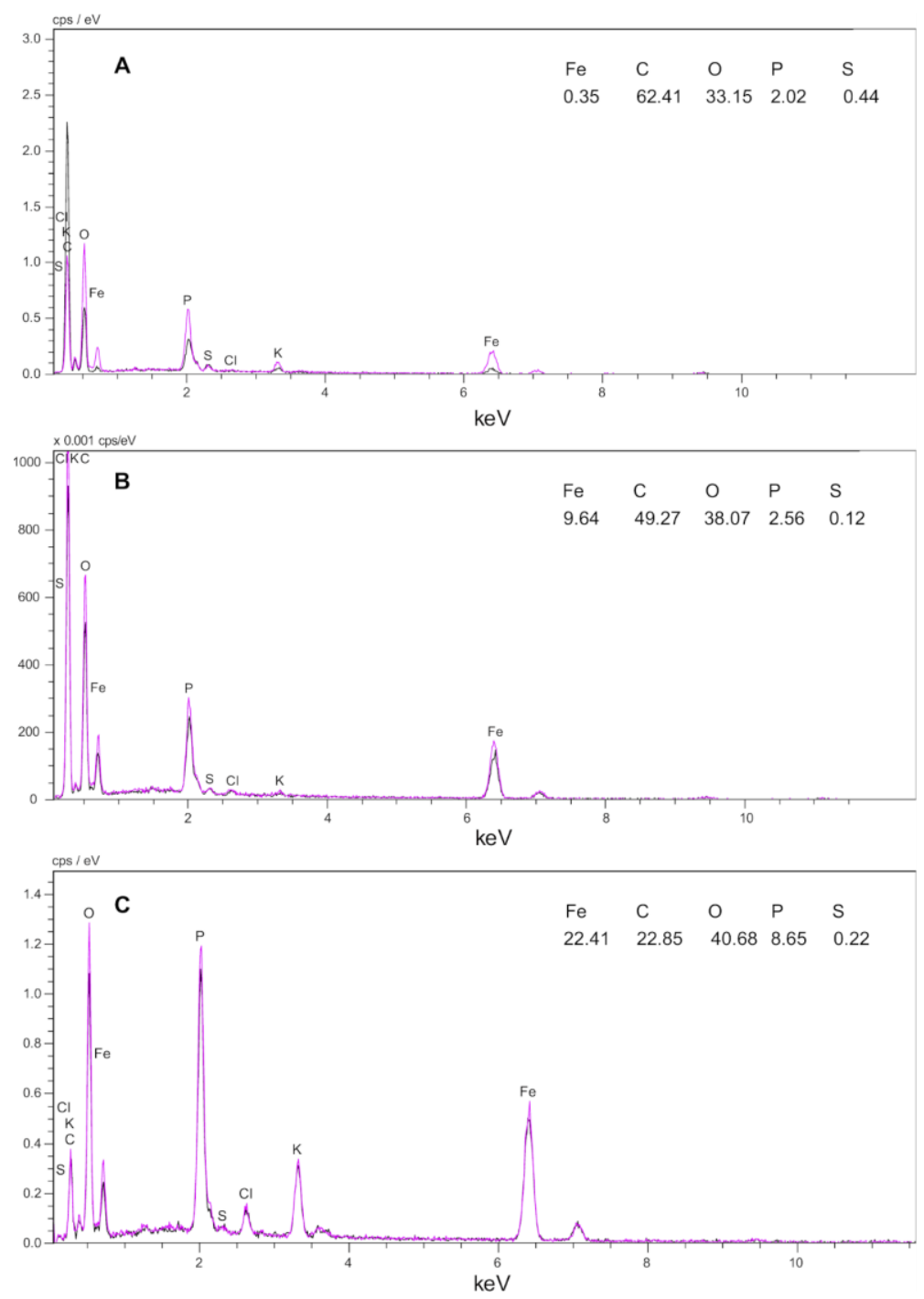

Figure 4. EDS analysis of strain PXL2 sediments at different temperatures (A corresponding Fig. 3A; B corresponding Fig. 3B; C corresponding Fig. 3C)

Based on the above analysis, we can see that low temperature environments had inhibitory effects on strain PXL2. At $5^{\circ} \mathrm{C}$, the cell morphology changed and the $\mathrm{Fe}$ content in sediment was extremely low and mainly existed in pericellular region instead of the cell surface while Temperature of $15^{\circ} \mathrm{C}$ seemed to have less of an effect on the 
metabolism of microorganisms, and the morphology of the cells remains the same, but the content of $\mathrm{Fe}$ was at least $50 \%$ lower than the sediment at $30^{\circ} \mathrm{C}$. Thus, $30^{\circ} \mathrm{C}$ is most suitable for the growth and metabolism of strain PXL2. Under this temperature, microbial metabolism is the fastest, and the rate of $\mathrm{Fe}$ oxidation and the content of $\mathrm{Fe}$ in sediment are the highest.

\section{Removal of arsenic by strain PXL2 at different temperatures}

The removal of arsenic at different temperatures is shown in Figure 5. The different amounts of arsenic are removed at different temperatures over time. After 7 days of treatment, total arsenic concentrations decreased from $70 \mu \mathrm{M}$ to $54.9 \mu \mathrm{M}, 34.2 \mu \mathrm{M}$ and $49.0 \mu \mathrm{M}$ at $5^{\circ} \mathrm{C}, 15^{\circ} \mathrm{C}$ and $30^{\circ} \mathrm{C}$, the removal rates were $21.6 \%, 51.1 \%$ and $30.0 \%$, respectively. The highest rate was at $15^{\circ} \mathrm{C}$.

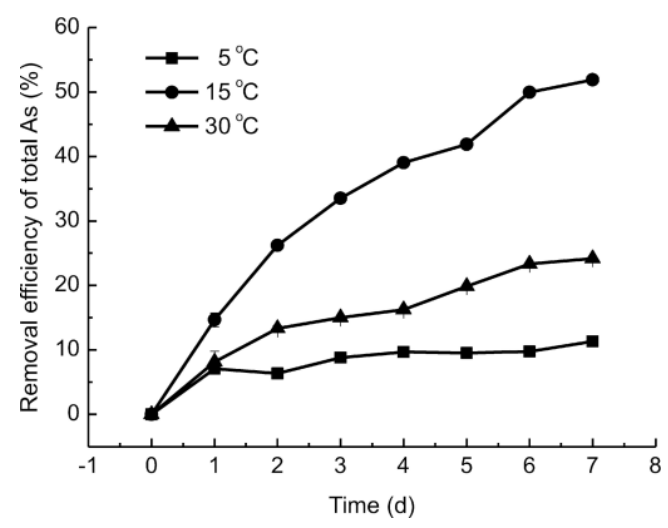

Figure 5. Total arsenic removal efficiency at different temperatures

Strain PXL2 has the ability to remove arsenic by arsenic oxidation. As seen in Figure 6, as total arsenic is removed, some As (III) is oxidized to As (V). At $5^{\circ} \mathrm{C}$ and $30^{\circ} \mathrm{C}$, with the removal of total arsenic, the concentration of As (III) decreased and the concentration of As (V) increased continuously. The percentage of As (III) in total arsenic dropped from the original $90 \%$ to $62.1 \%$ and $54.0 \%$, respectively. The corresponding As (V) concentrations increased from $10 \%$ to $37.9 \%$ and $46.0 \%$, respectively. The conversion of As (III) to As (V) at $15^{\circ} \mathrm{C}$ is less pronounced with respect to the other conversions at two temperature, but some of the As (V) production can be seen.

From the above analysis we can see that temperatures that are too high or too low are not suitable for strain PXL2 arsenic removal, with $15^{\circ} \mathrm{C}$ being the most suitable temperature. One of the reasons may be that enzyme catalysis in microbial metabolism is inhibited severely at extreme low and high temperatures. Compared with the medium temperature, microbial metabolism is active in high temperature environments, and therefore results in the fastest ferrous oxide oxidation rate. The rate of ferrous oxidation directly affects the type of oxidation product. Different types of iron oxides have different arsenic adsorption capacities. The environment of oxidative denitrification of AFODN anaerobic ferrous compounds is mainly for the pollution of nitrate and arsenic in groundwater. The perennial groundwater temperature is maintained at $15^{\circ} \mathrm{C} \sim 17^{\circ} \mathrm{C}$, which is very conducive to AFODN reproductive metabolism and enzyme catalysis. Therefore, strain PXL2 is suitable for applications to groundwater pollution control. 

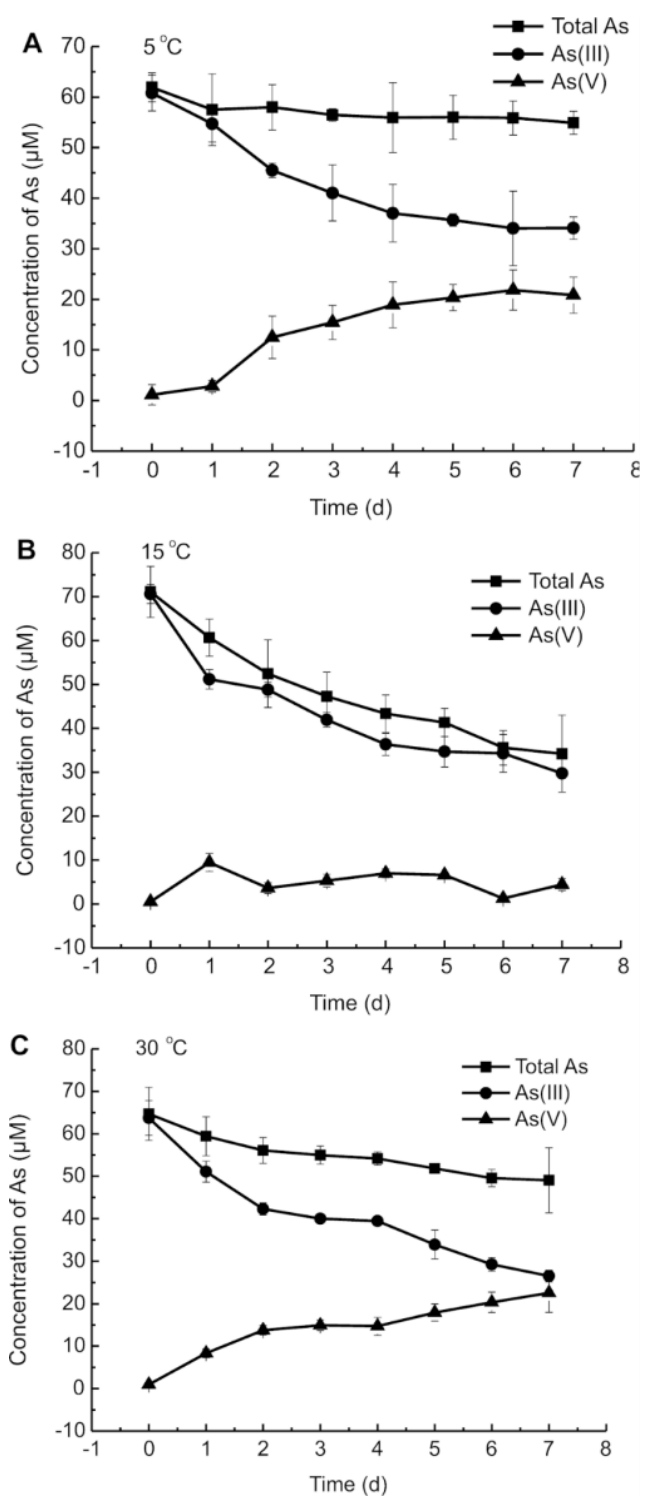

Figure 6. Time profile of As concentrations in the strain PXL2 culture at different temperatures

\section{Conclusion}

Growth of strain PXL2 was significantly inhibited at $5^{\circ} \mathrm{C}$. At this temperature, morphological changes were also seen, where a rod-like shape changed to a spherical one, and dents appeared on the bacterial surface. Under this condition, the denitrification ability and Fe (II) capacity of the strain decreased significantly. The As removal ability was also affected. The total arsenic removal rate was at $21.6 \%$. At $15^{\circ} \mathrm{C}$, the metabolic rate of growth, denitrification and Fe (II) oxidation rate were slightly lower than $30^{\circ} \mathrm{C}$, but the total arsenic removal rate was the highest at this temperature, at $51.1 \%$. The total arsenic removal rate at $30^{\circ} \mathrm{C}$ was $30.0 \%$. On the whole, the strain PXL2 metabolized well at $15^{\circ} \mathrm{C}$, and was found to be suitable for treating nitrate and arsenic contamination in groundwater. This biological treatment has promising applications in future projects. This research promotes the research of ferrous anaerobic micro-organisms in this new field of research. 
Acknowledgements. This work was supported by National Science Foundation of Xinjiang Uygur Autonomous Region, China (2016D01A028).

\section{REFERENCES}

[1] Benz, M., Brune, A., Schink, B. (1998): Anaerobic and aerobic oxidation of ferrous iron at neutral $\mathrm{pH}$ by chemoheterotrophic nitrate-reducing bacteria. - Archives of Microbiology 69: 159-165.

[2] Chakraborty, A., Roden, E. E., Schieber, J. (2011): Enhanced Growth of Acidovorax sp. Strain 2AN during Nitrate-Dependent Fe(II) Oxidation in Batch and Continuous-Flow Systems. - Applied and Environmental Microbiology 77: 8548-8556.

[3] Chen, D. D., Liu, T. X., Li, X. M. (2018): Biological and chemical processes of microbially mediated nitrate-reducing $\mathrm{Fe}$ (II) oxidation by Pseudogulbenkiania sp. strain 2002. - Chemical Geology 476: 59-69.

[4] Cui, J. L., Du, J. J., Tian, H. X. (2018): Rethinking anaerobic As(III) oxidation in filters: Effect of indigenous nitrate respirers. - Chemosphere 196: 223-230.

[5] Ehrenreich, A., Widdel, F. (1994): Anaerobic oxidation of ferrous iron by purple bacteria, a new type of phototrophic metabolism. - Applied and Environmental Microbiology 60: 4517-4526.

[6] Gendel, Y., Lahav, O. (2008): Accurate determination of Fe(II) concentrations in the presence of a very high soluble Fe (III) background. - Applied Geochemistry 23: 21232129.

[7] Geng, Y. J., Wu, Q., Muszynski, M. (1996): Apoptosis of Vascular Smooth Muscle Cells Induced by In Vitro Stimulation with Interferon- $\gamma$, Tumor Necrosis Factor- $\alpha$, and Interleukin-1ß. -Arteriosclerosis. - Thrombosis, and Vascular Biology 16: 19-27.

[8] Guo, X. J., Fujino, Y., Kaneko, S. (2001): Arsenic contamination of groundwater and prevalence of arsenical dermatosis in the Hetao plain area, Inner Mongolia, China. Molecular and Cellular Biochemistry 222: 137-140.

[9] Hafenbradl, D., Keller, M., Dirmeier, R. (1996): Ferroglobus placidus gen. nov., sp. nov., a novel hyperthermophilic archaeum that oxidizes $\mathrm{Fe}^{2+}$ at neutral $\mathrm{pH}$ under anoxic conditions. - Archives of Microbiology 166: 308-314.

[10] Hansen, H. C. B., Koch, C. B., Nancke-Krogh, H. (1996): Abiotic nitrate reduction to ammonium: key role of green rust. - Environmental Science \& Technology 30: 20532056.

[11] Hu, S., Shi, Q. T., Jing, C. Y. (2015): Groundwater arsenic adsorption on granular TiO2: integrating atomic structure, filtration, and health impact. - Environmental Science \& Technology 49: 9707-9713.

[12] Kappler, A., Schink, B., Newman, D. K. (2005): Fe (III) mineral formation and cell encrustation by the nitrate-dependent Fe (II)-oxidizer strain BoFeN1. - Geobiology 3: 235-245.

[13] Karim, M. M. (2000): Arsenic in groundwater and health problems in Bangladesh. Water Research 34: 304-310.

[14] Klueglein, N., Kappler, A. (2013): Abiotic oxidation of Fe(II) by reactive nitrogen species in cultures of the nitrate-reducing Fe(II) oxidizer Acidovorax sp. BoFeN1 questioning the existence of enzymatic Fe(II) oxidation. - Geobiology 11: 180-190.

[15] Leahy, J. G., Colwell, R. R. (1990): Microbial Degradation of Hydrocarbons in Environment. - Microbiological Reviews 54: 305-315.

[16] Li, B. H., Tian, C. Y., Zhang, D. Y. (2014): Anaerobic Nitrate-Dependent Iron (II) Oxidation by a Novel Autotrophic Bacterium, Citrobacter freundii Strain PXL1. Geomicrobiology Journal 31(2): 138-144. 
[17] Li, B. H., Pan, X. L., Zhang, D. Y. (2015): Anaerobic nitrate reduction with oxidation of $\mathrm{Fe}$ (II) by Citrobacter Freundii strain PXL1-a potential candidate for simultaneous removal of As and nitrate from groundwater. - Ecological Engineering 77: 196-201.

[18] Li, B. H., Deng, C. N., Zhang, D. Y. (2016): Bioremediation of Nitrate- and ArsenicContaminated Groundwater Using Nitrate-Dependent Fe(II) Oxidizing Clostridium sp. Strain pxl2. - Geomicrobiology Journal 33: 185-193.

[19] Li, Y. F., Long, X. X., Chong, Y. X. (2017): Characterization of the cell Fe mineral aggregate from nitrogen removal employing ferrous and its adsorption features to heavy metal. - Journal of Cleaner Production 156: 538-548.

[20] Niazi, N. K., Bibi, I., Shahid, M. (2018): Arsenic removal by perilla leaf biochar in aqueous solutions and groundwater: an integrated spectroscopic and microscopic examination. - Environmental Pollution 232: 31-41.

[21] Ottley, C. J., Davison, W., Edmunds, W. M. (1997): Chemical catalysis of nitrate reduction by iron(II). - Geochimica et Cosmochimica Acta 61: 1819-1828.

[22] Shen, X. Y., Zhang, L. M., Shen, J. P. (2010): Soil type determines the abundance and community structure of ammonia-oxidizing bacteria and archaea in flooded paddy soils. Journal of Soils and Sediments 10: 1510-1516.

[23] Singh, N., Kumar, D., Sahu, A. (2007): Arsenic in the environment: effects on human health and possible prevention. - Journal of Environmental Biology 28: 359-365.

[24] Smedley, P. L., Kinniburgh, D. G. (2002): A review of the source, behaviour and distribution of arsenic in natural waters. - Applied Geochemistry 17: 517-568.

[25] Song, P. P., Yang, Z. H., Zeng, G. M. (2017): Electrocoagulation treatment of arsenic in wastewaters: A comprehensive review. - Chemical Engineering Journal 317: 707-725.

[26] Straub, K. L., Benz, M., Schink, B. (1996): Anaerobic, nitrate dependent microbial oxidation of ferrous iron. - Applied and Environmental Microbiology 62: 1458-1460.

[27] Straub, K. L., Rainey, F. A., Widdel, F. (1999): Rhodovulum iodosum sp. Nov. and Rhodovulum robiginosum sp. Nov., two new marine phototrophic ferrous-iron-oxidizing purple bacteria. - International Journal of Systematic Bacteriology 49: 729-735.

[28] Straub, K. L., Schonhuber, W. A., Buchholz-Cleven, B. E. E. (2004): Diversity of ferrous iron-oxidizing, nitrate reducing bacteria and their involvement in oxygen independent iron cycling. - Geomicrobiology Journal 21: 371-378.

[29] Sun, G. F. (2004): Arsenic contamination and Arsenicosis in China. - Toxicology and Applied Pharmacology 198: 268-271.

[30] Veena, K., Narayana, B. (2009): Spectrophotometic determination of nitrite using new coupling agents. - Indian Journal of Chemical Technology 16: 89-92.

[31] Wang, L. F., Huang, J. Z. (1994): Chronic arsenism from drinking water in some areas of Xinjiang, China. - In: Nriagu, J. O. (ed.) Arsenic in the Environment, Part II: Human Health and Ecosystem Effects. John Wiley and Sons Inc.: New York 159-172.

[32] Wang, S. X., Wang, Z. H., Cheng, X. T. (2007): Arsenic and fluoride exposure in drinking water: children's IQ and growth in Shanyin County, Shanxi Province, China. Environmental Health Perspectives 115: 643-647.

[33] Weber, K. A., Pollock, J., Cole, K. A. (2006): Anaerobic nitrate-dependent iron (II) biooxidation by a novel lithoautotrophic betaproteobacterium, strain 2002. - Applied and Environmental Microbiology 72: 686-694.

[34] Wu, G. Y., Zhang, D. Y., Pan, X. L. (2010): Anaerobic oxidation of ferrous iron by microbial mixture and its potential to remove mercury and nitrate from the groundwater. - Research Journal of Chemistry and Environment 14: 36-39.

[35] Xing, S. H., Chen, C. R., Zhou, B. Q. (2010): Soil soluble organic nitrogen and microbial processes under adjacent coniferous and broadleaf plantation forests. - Journal of Soils and Sediments 10: 748-757.

[36] Zhang, W., Li, X. M., Liu, T. X. (2014): Competitive reduction of nitrate and iron oxides by Shewanella putrefaciens 200 under anoxic conditions. - Colloids and Surfaces A: Physicochemical Engineering Aspects 445: 97-104. 